\title{
Influence of Pigeon Manure Tea on some Physiological and Genetical Parameters of Sugar Beet
}

\author{
El-Araby S.R. Salem ${ }^{1}$, Sahar F. Tawfik ${ }^{2}$ and Mohamed A. Ghonema ${ }^{3}$
}

\begin{abstract}
Two field experiments were carried out in 2013/2014 and 2014/2015 seasons at Nubaria Research Station, ElBeheira Governorate, Egypt to study the response of three sugar beet cultivars to the foliar nutrition with pigeon manure tea (PMT) in combination with soil $\mathbf{N}$ fertilizer and its effect on yield, yield components, chemical constituents and some physiological and genetical parameters. A split plot arrangement in a Randomized Complete Block Design with three replications was used. Three polygerm sugar beet cultivars namely SN-626, NH627 and Hercule were randomly distributed in the main plots, while the four combinations of PMT and N fertilizer were randomly distributed in the sub-plots, it was as follows; $80 \mathrm{~kg} \mathrm{~N} / \mathrm{fed}$ (recommended level) was given as soil application, without PMT (check treatment) (C1), foliar application of $2.5 \%$ PMT + soil addition of $40 \mathrm{~kg} \mathrm{~N} / \mathrm{fed}$ (C2), foliar application of $5 \%$ PMT + soil addition of $40 \mathrm{~kg}$ N/fed (C3) and foliar application of $10 \%$ PMT + soil addition of $40 \mathrm{~kg} \mathrm{~N} / \mathrm{fed}(\mathrm{C} 4)$. The results illustrated that fertilizing the tested cultivars with $(\mathrm{C} 4)$ treatment attained the highest mean of sugar yield compared with (C2) and/or (C3), in the two seasons. The three cultivars showed that the highest and the least values of root, top, sugar yields and sucrose\% were produced from SN-626 and Hercule cultivar, respectively, in both seasons. Genotypic and phenotypic variances, heritability and coefficient of variance as percent of means were estimated for the studied traits. Maximum heritability values were obtained for root diameter followed by top yield. Meanwhile, it was moderate for sugar yield, sucrose \% and root yield, while the minimum values of heritability were recorded by total soluble solids and purity percentages. Besides, different genetic coefficient of variance as percent of mean, as well as high genetic variability and high range of variations were detected. Path-coefficient analysis revealed that the improvement of different genotypes sugar yield can alter the relative importance of root yield, sucrose $\%$ and purity \%. Under conditions of the present work, it can be recommended that growing $\mathrm{SN}-626$ variety fertilized with (C4) treatment produced the highest sugar yield/fed with no significant difference from treating the same variety with $\mathrm{C} 1$ (recommended level). Also, the data suggest that significant improvement could be achieved by increasing purity as well as sucrose percentages to increase sugar yield.
\end{abstract}

Key words: Beta vulgaris, cultivars, Manure tea, Physiological, Genetical Parameters, Sugar yield.

\footnotetext{
${ }^{1}$ Physiol. Chem., ${ }^{2}$ Agron. and ${ }^{3}$ Breed. Gen. Depts. Sugar Crop Res. Inst., Agric. Res. Center, Giza, Egypt Received May 20, 2018, Accepted June 12, 2018
}

\section{INTRODUCTION}

In Egypt, sugar production depends on sugar beet and sugarcane. Nowadays, sugar beet becomes the first source of sugar and shares $57.61 \%$ (1.347 million tons). The total cultivated area with sugar beet in 2016/2017 reached 511 thousand feddans, with an average productivity of 16.7 tons of roots/fed., which is considered very low (SCC 2017).

In Egypt, sugar beet growers got used to increase the mineral or inorganic nitrogen fertilizers given to their crop aiming at raising its productivity per unit area, regardless of the negative impacts of this practice on beet quality, in addition to pollution of the ground water (Gharib and EL-Henawy,2011). Moreover, grower's net return decreased due to the ascendant increase in the price of mineral $\mathrm{N}$ fertilizers. However, the manure of cattle or poultry is considered environmentally friendly, play a significant role in the crop production, help to build up the lost micro flora and improve the soil fertility (Zhang et al., 2013).

Manure-based extracts are a soluble nutrient source made from raw, disinfected animal manure soaked in water. For all practical purposes, manure tea is prepared in the same way as the compost extracts. However, the manure is placed in a burlap sack and suspended in a barrel of water for 7 to 14 days. The primary benefit of the manure tea will be a supply of soluble nutrients, which can be used as a liquid fertilizer (Diver 2002).

Pigeon manure tea was used as organic fertilizer. Adding the pigeon manure tea with decreasing the percentage of NPK $(75 \%)$ led to increase the seedlings parameters (Haggag et al., 2015). Also, manure tea dissolves the nutrients from manure into water to feed plants and soil. In addition, bovine manure tea was used to control some diseases (Ingham, 2005). There is limited information on the effect of pigeon manure tea (PMT) on sugar beet in arid and semi-arid climates.

On the other hand, the additional information regarding the genetic parameters as genotypic coefficient of variation as percent of mean helps in selecting a proper methodology for genetic improvement of the trait. The success of plant breeding depends on the extent of genetic variations in a crop. Knowledge on the nature and magnitude of genetic 
variation governing the inheritance of quantitative characters like yield and its components is essential for genetic improvement. A critical analysis of genetic variability present in the germplasm of a crop and its estimation is a pre-requisite for initiating any crop improvement program as well as adopting appropriate selection techniques (Ajmera et al., 2017). Heritability indicates the extent of transmissibility of a character into future generations. Moreover, knowledge of heritability is also essential for selection of component traits for yield improvement. Heritability estimates along with genetic advance is normally more helpful in predicting the genetic gain of selection than heritability estimates alone (Ajmera et al., 2017). Broad sense heritability is the ratio of genotypic variance to total or phenotypic variance.

The objective of this study was to examine the effect of replacing mineral fertilizers partially using an organic fertilizer (pigeon manure tea) as foliar application on growth, quality, sugar and root yields of sugar beet, as well as to evaluate the performance and some genetic parameters of different characters for three sugar beet varieties. Besides, to determine the order of importance of root yield, sucrose percentage, and purity percent in determining sugar yield of three sugar beet cultivars.

\section{MATERIALS AND METHODS}

Two field experiments were carried out in 2013/14 and 2014/15 seasons at Nubaria Research Station (latitude of $30^{\square} 54^{`} 30.468^{\prime \prime} \quad \mathrm{N}$ and longitude of $29 \square$ 57 58.973" E), El-Beheira Governorate, Egypt to study the response of three sugar beet cultivars to four combinations of foliar nutrition with pigeon manure tea (PMT) and nitrogen soil application on yield, yield components, chemical constituents as well as some physiological and genetical parameters.

A randomized complete block design, in a split plot distribution, with three replications was used. Three polygerm sugar beet varieties namely SN-626, NH-627 and Hercule were sown in the main plots, while the four combinations of PMT and nitrogen fertilizer were randomly applied in the sub-plots, which were as follows:

- $\mathrm{C} 1: 80 \mathrm{~kg} \mathrm{~N} / \mathrm{fed}$ (recommended level) was given as soil application, without PMT (check treatment).

- C2: foliar application of $2.5 \%$ PMT + soil application of $40 \mathrm{~kg} \mathrm{~N} / \mathrm{fed}$.

- C3: foliar application of 5\% PMT + soil application of $40 \mathrm{~kg} \mathrm{~N} / \mathrm{fed}$.

- C4: foliar application of $10 \%$ PMT + soil application of $40 \mathrm{~kg} \mathrm{~N} / \mathrm{fed}$.

Sub-plot area was $21 \mathrm{~m}^{2}$ including 6 ridges of $0.5 \mathrm{~m}$ width and $7.0 \mathrm{~m}$ long. Pigeon manure tea was applied at 60, 75 and 90 days after sowing. Nitrogen fertilizer was added as ammonium nitrate $(33.5 \%)$ in two equal doses; after thinning at 35 days after sowing and 20 days later.

\section{Preparation of pigeon manure tea (PMT)}

Pigeon manure tea (PMT) was used as an organic fertilizer, which was prepared by collecting dry pigeon manure (PM) in closed burlap bags, which were immersed into plastic barrel containing water at the ratio of 10:100 w/v. It was left for two weeks, with stirring once a day. Thereafter, bags of PM was hauled out from water and squeezed to get their extracts. This type of brewing practice is call "passive" or non - aerated manure tea as reported by Ingham (2005). The amount of PMT (10\%) was diluted to prepare another two concentrations of $5 \%$ and $2.5 \%$.

Sugar beet varieties were sown on the $14^{\text {th }}$ and $17^{\text {th }}$ of October in the first and second season, respectively. Phosphorus fertilizer was added as calcium super

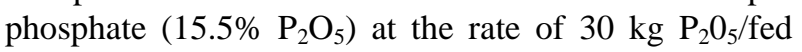
during seed bed preparation, while potassium was added as potassium sulphate at the rate of $48 \mathrm{~kg}$ $\mathrm{K}_{2} \mathrm{O} / \mathrm{fed}$, with the $2^{\text {nd }}$ dose of nitrogen fertilizer.

Some characteristics of the experimental soil and the used pigeon manure as well as manure extract were determined according to the method of Black (1965) and Page (1982) as shown in Tables 1 and 2.

Table 1. Some physical and chemical properties of the soil of the experimental site

\begin{tabular}{|c|c|c|c|c|c|c|c|c|c|c|c|c|c|c|c|c|c|}
\hline \multicolumn{3}{|c|}{$\begin{array}{c}\text { Physical properties } \\
\text { particle size }\end{array}$} & \multirow{3}{*}{$\begin{array}{c}\text { pH } \\
(1: 2.5)\end{array}$} & \multirow{3}{*}{$\begin{array}{l}\text { E.C. } \\
\text { ds/m }\end{array}$} & \multirow{3}{*}{$\begin{array}{c}\text { Organic } \\
\text { Matter } \\
\%\end{array}$} & \multicolumn{9}{|c|}{ Soil chemical properties } & \multirow{2}{*}{\multicolumn{3}{|c|}{$\begin{array}{c}\text { available } \\
\text { contents (ppm) }\end{array}$}} \\
\hline $\begin{array}{c}\text { Sand } \\
\%\end{array}$ & Silt \% & $\begin{array}{c}\text { Clay } \\
\%\end{array}$ & & & & \multirow[b]{2}{*}{$\mathrm{CaCo}_{3}$} & \multicolumn{4}{|c|}{ Soluble cations (meq/l) } & \multicolumn{4}{|c|}{ Soluble anions (meq/l) } & & & \\
\hline Text & $\begin{array}{l}\text { ure }: S z \\
\text { loam }\end{array}$ & ndy & & & & & ${ }^{++} \mathbf{C a}$ & ${ }^{++} \mathbf{M g}$ & ${ }^{+} \mathbf{N a}$ & ${ }^{+} \mathbf{K}$ & ${ }^{-} \mathrm{CO}_{3}$ & ${ }^{-} \mathrm{HCO}_{3}$ & ${ }^{-} \mathbf{C l}$ & ${ }^{-} \mathrm{SO}_{4}$ & $\mathbf{N}$ & $\mathbf{P}$ & $\mathbf{K}$ \\
\hline \multicolumn{18}{|c|}{$2013 / 14$} \\
\hline \multicolumn{18}{|c|}{$2014 / 15$} \\
\hline 67.4 & 21.3 & 11.3 & 8.1 & 1.6 & 0.87 & 7.2 & 3.20 & 3.9 & 4.9 & 0.2 & 0.31 & 0.84 & 7.3 & 8.33 & 14 & 6.9 & 69.3 \\
\hline
\end{tabular}


Table 2. Chemical composition of dry pigeon manure and PMT

\begin{tabular}{|c|c|c|c|c|c|c|c|c|c|c|}
\hline \multirow{2}{*}{ E.C ds/m } & \multirow{2}{*}{ OM\% } & \multirow{2}{*}{ pH } & \multirow{2}{*}{ Total C\% } & \multirow{2}{*}{ Total N\% } & \multirow{2}{*}{ Total P\% } & \multirow{2}{*}{ Total K\% } & \multicolumn{4}{|c|}{ Available micronutrients $\mu \mathrm{g} / \mathrm{g}$} \\
\hline & & & & & & & $\mathbf{F e}$ & Mn & $\mathbf{Z n}$ & $\mathbf{C u}$ \\
\hline \multicolumn{11}{|c|}{ Pigeon manure } \\
\hline 7.61 & 68.4 & 6.44 & 32.8 & 3.99 & 0.94 & 0.96 & 237.3 & 48.6 & 93.74 & 8.59 \\
\hline \multicolumn{11}{|c|}{ Pigeon manure Tea (PMT) 10\% } \\
\hline 3.48 & -- & 8.18 & -- & 2.46 & 0.69 & 0.51 & 16.9 & 7.9 & 7.7 & 1.7 \\
\hline
\end{tabular}

Samples of ten plants were chosen at random from It was calculated according to the equation of Silin and the inner rows of each sub plot at 130, 160 and 190 days after sowing in both seasons to determine the following traits:

\section{Growth traits}

Leaf area index (LAI) was estimated according to the following equation:

LAI = leaf area/plant land area

Where, leaf area was determined by the disk method using 10 disks of $1.0 \mathrm{~cm}$ diameter as shown by Watson (1952).

Crop Growth Rate CGR (g/day) in the period (between 130 and 160 days) and (160 and 190 days). It was calculated according to the following equation:

$\mathrm{CGR}=\mathrm{W}_{2}-\mathrm{W}_{1} / \mathrm{T}_{2}-\mathrm{T}_{1}$

Where: $\mathrm{W}_{1}$ and $\mathrm{W}_{2}$ refer to total dry weight at time $\mathrm{T}_{1}$ and $\mathrm{T}_{2}$, respectively.

At harvest (190 days), samples of ten random and guarded plants were taken to study the following parameters:

\section{Root growth traits}

Root fresh weight $(\mathrm{g})$.

Root length $(\mathrm{cm})$.

Root diameter (cm).

\section{Sugar beet yields}

Top yield/fed (ton).

Root yield/fed (ton).

Theoretical sugar yield/fed (ton).

It was calculated according to the following equation:

Theoretical sugar yield/fed (ton) $=$ root yield/fed (ton) $\times$ sucrose $\%$

\section{Sugar quality traits}

Sucrose percentage $(\%)$.

It was determined polarmetrically according to method of Le-Docte (1927).

Total soluble solids percentage (TSS \%).

It was determined using hand "Refractometer".

Purity percentage $(\%)$. Silina (1977) as follows:

Purity percentage $=($ Sucrose $\% / \mathrm{TSS} \%) \times 100$

The collected data were statistically analyzed according to Snedecor and Cochran (1994). The least significant difference (LSD at 5\%) was used to compare treatments means.

\section{Genetic parameters}

\section{Genotypic and phenotypic variance}

The genotypic and phenotypic variances were calculated as the formulae of Burton (1952).

(Mean square of character - Mean square of error)

Genotypic variance $\left(\sigma^{2} \mathrm{~g}\right)=$

$$
\text { Number of replications }
$$

Phenotypic variance $\left(\sigma^{2} \mathrm{p}\right)=\left(\sigma^{2} \mathrm{~g}\right)+\left(\sigma^{2} \mathrm{e}\right)$

$\left(\sigma^{2} \mathrm{e}\right)=$ Error variance

\section{Genotypic and phenotypic coefficients of variability}

The genotypic and phenotypic coefficients of variation were calculated according to the equation given by Falconer (1964).

Genotypic Coefficient of variability $=($ Genotypic standard deviation/ Mean) $\times 100$

Phenotypic Coefficient of variability $=$ (Phenotypic standard deviation/ Mean) $\times 100$

The range of variation categorized as proposed by Sivasubramanian and Madhavamenon (1973):

$<10 \%$ : low10-20\%: moderate >20\%: high

\section{Heritability}

Heritability in the broad sense refers to the proportion of genotypic variance to the total observed variance in the total population (phenotypic variances). Heritability $\left(h^{2}\right)$ in the broad sense was calculated according to the formula given by Allard (1999).

$h^{2}=\sigma^{2} \mathrm{~g} / \sigma^{2} \mathrm{p}$

Where:

$\mathrm{h}^{2}=$ heritability in broad sense $\sigma^{2} \mathrm{~g}=$ genotypic variance

$\sigma^{2} \mathrm{p}=$ phenotypic variance $\left(\sigma^{2} \mathrm{~g}\right)+\left(\sigma^{2} \mathrm{e}\right) \sigma^{2} \mathrm{e}=$ environmental variance

As suggested by Johnson et al. (1955) $\left(\mathrm{h}^{2}\right)$ estimates were categorized as follows: 
Low: 0-30\% Medium: 30-60\% High: above 60\%

\section{Correlation}

Correlation coefficients were computed among studied traits according to Steel et al. (1997).

\section{Path-coefficient}

Path-coefficient analyses were computed as described by Li (1956).

\section{RERSULTS AND DISCUSSION}

\section{Growth attributes}

\section{Leaf area index (LAI)}

As seen in Table (3) LAI, generally increased by increasing the age of plant. The studied cultivars were significantly differed in leaf area index (LAI) at 130, 160 and 190 days in both seasons, except the two cultivars NH-627 and Hercule which were insignificantly differed at 130 and 190 in the first season. Wherever, the highest values of LAI at 130, 160 and 190 days were recorded by SN-626 cultivar in both tested seasons except LAI at 130 days in the $2^{\text {nd }}$ season, NH-627 owned the highest LAI. On the other hand, the lowest values of LAI were recorded by Hercule cultivar. Differences among varieties were also reported by Ilkaee et al. (2016).

Table 3. Effects of the combinations of pigeon manure tea and mineral nitrogen (PMT-N) on leaf area index (LAI) at 130, $160 \& 190$ days of three sugar beet cultivars

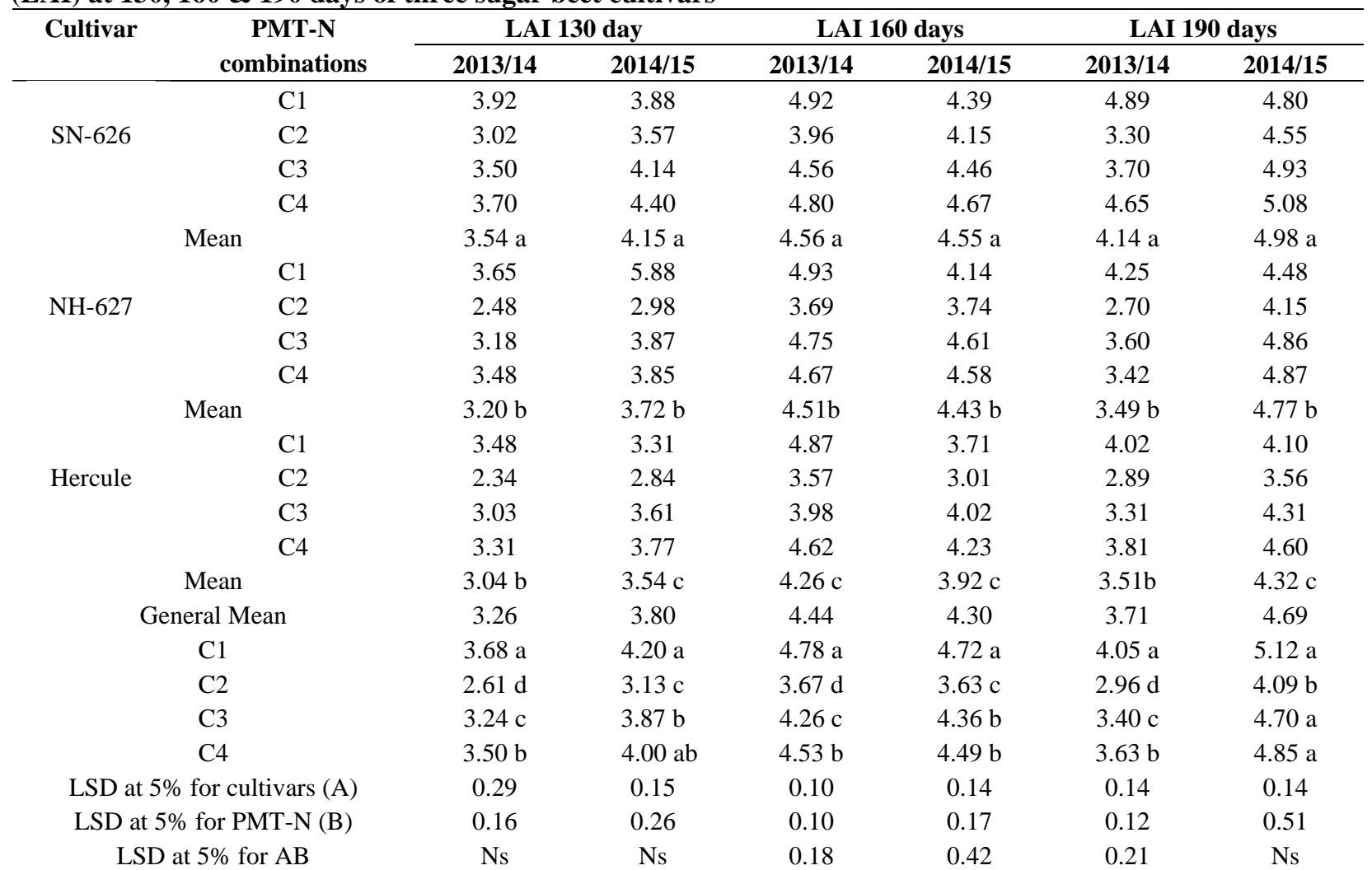
treatment $(\mathrm{C} 1)$ significantly increased LAI compared with the tested treatments in both tested seasons. By contrast, C2 treatment had the lowest values. These results are in a line with Akl et al. (2017) in Egypt who reported that superior grapevines leaf area was remarkably stimulated in response to spraying with chicken manure tea. Data in Table (3) also illustrated that there was insignificant interaction effect between the tested beet varieties and PMT-N treatments in leaf area index (LAI) at 130 days in both seasons and 190 days in the second season. The differences among treatments $\mathrm{C} 1, \mathrm{C} 2, \mathrm{C} 3$ and $\mathrm{C} 4$ in their effect on LAI at 130,160 and 190 days were significant in the three tested varieties in both seasons.

\section{Crop growth rate (CGR)}

In comparison with crop growth rates (CGR) at 130160 and 160-190 days for tested sugar beet cultivars, data in Table 4 reflected that, there were significant differences among the studied sugar beet cultivars, except between NH-627 and Hercule cultivars. Where, the highest CGR values through 130-160 and 160-190 days were produced by SN-626 cultivar in both seasons, consequently the CGR values of $\mathrm{NH}-627$ were higher 
Table 4. Effects of the combinations of pigeon manure tea and mineral nitrogen (PMT-N) on crop growth rate (CGR) g/day between (130-160) and (160-190) days of three sugar beet cultivars

\begin{tabular}{|c|c|c|c|c|c|}
\hline \multirow[t]{2}{*}{ Cultivar } & \multirow[t]{2}{*}{ PMT-N combinations } & \multicolumn{2}{|c|}{ CGR130-160 days } & \multicolumn{2}{|c|}{ CGR160-190 days } \\
\hline & & $2013 / 14$ & $2014 / 15$ & 2013/14 & $2014 / 15$ \\
\hline \multirow{4}{*}{ SN-626 } & $\mathrm{C} 1$ & 3.02 & 2.30 & 3.91 & 1.88 \\
\hline & $\mathrm{C} 2$ & 2.79 & 2.23 & 1.22 & 1.25 \\
\hline & $\mathrm{C} 3$ & 2.74 & 2.50 & 1.69 & 1.19 \\
\hline & $\mathrm{C} 4$ & 2.86 & 2.58 & 3.71 & 2.81 \\
\hline \multicolumn{2}{|c|}{ Mean } & $2.85 \mathrm{a}$ & $2.51 \mathrm{a}$ & $2.63 \mathrm{a}$ & $2.05 \mathrm{a}$ \\
\hline \multirow{4}{*}{ NH-627 } & $\mathrm{C} 1$ & 2.19 & 1.31 & 1.64 & 1.78 \\
\hline & $\mathrm{C} 2$ & 1.54 & 1.05 & 1.43 & 1.70 \\
\hline & $\mathrm{C} 3$ & 2.17 & 1.18 & 1.63 & 2.35 \\
\hline & $\mathrm{C} 4$ & 2.08 & 1.62 & 1.57 & 1.77 \\
\hline \multirow[t]{2}{*}{ Mean } & & $2.00 \mathrm{~b}$ & $1.39 \mathrm{~b}$ & $1.57 \mathrm{~b}$ & $1.92 \mathrm{~b}$ \\
\hline & $\mathrm{C} 1$ & 2.10 & 1.29 & 1.86 & 1.80 \\
\hline \multirow[t]{3}{*}{ Hercule } & $\mathrm{C} 2$ & 1.43 & 1.19 & 1.13 & 1.25 \\
\hline & $\mathrm{C} 3$ & 1.51 & 1.31 & 2.20 & 2.31 \\
\hline & $\mathrm{C} 4$ & 2.00 & 1.43 & 1.75 & 2.04 \\
\hline \multicolumn{2}{|c|}{ Mean } & $1.76 \mathrm{~b}$ & $1.36 \mathrm{~b}$ & $1.74 \mathrm{~b}$ & $1.93 \mathrm{~b}$ \\
\hline \multicolumn{2}{|c|}{ General Mean } & 2.20 & 1.75 & 1.98 & 1.97 \\
\hline \multicolumn{2}{|c|}{$\mathrm{C} 1$} & $2.31 \mathrm{ab}$ & $1.88 \mathrm{a}$ & $2.34 \mathrm{a}$ & $2.21 \mathrm{a}$ \\
\hline \multicolumn{2}{|c|}{$\mathrm{C} 2$} & $1.92 \mathrm{c}$ & $1.49 \mathrm{~b}$ & $1.26 \mathrm{c}$ & $1.40 \mathrm{c}$ \\
\hline \multicolumn{2}{|c|}{$\mathrm{C} 3$} & $2.14 \mathrm{~b}$ & $1.66 \mathrm{ab}$ & $1.84 \mathrm{~b}$ & $1.95 \mathrm{~b}$ \\
\hline \multicolumn{2}{|c|}{$\mathrm{C} 4$} & $2.44 \mathrm{a}$ & $1.98 \mathrm{a}$ & $2.47 \mathrm{a}$ & $2.32 \mathrm{a}$ \\
\hline \multicolumn{2}{|c|}{ LSD at $5 \%$ for cultivars (A) } & 0.27 & 0.19 & 0.62 & 0.12 \\
\hline \multicolumn{2}{|c|}{ LSD at $5 \%$ for PMT-N (B) } & 0.17 & 0.26 & 0.15 & 0.23 \\
\hline \multicolumn{2}{|c|}{$\mathrm{LSD}$ at $5 \%$ for $\mathrm{AB}$} & 0.30 & Ns & 0.26 & 0.56 \\
\hline
\end{tabular}

C1: $80 \mathrm{~kg} \mathrm{~N} /$ fed (recommended level), without PMT (check treatment) C2: $40 \mathrm{~kg} \mathrm{~N} / \mathrm{fed}+\mathrm{PMT}$ at $2.5 \%$

C3: $40 \mathrm{~kg} \mathrm{~N} / \mathrm{fed}+\mathrm{PMT}$ at 5\%

than Hercule in 130-160 days without significant differences in both tested seasons. Differences among varieties were reported by Ilkaee et al. (2016) and Moosavi et al. (2017).

On the other hand, PMT-N caused significant positive effect on CGR. Where, the highest values of CGR through 130-160 and 160-190 days were recorded by $\mathrm{C} 4$ treatment which didn't significantly differ from C1 (recommended level) treatment in both seasons. The increase in CGR may be due to the effect of micronutrients in PMT which compensated the less availability of micronutrients because soil in experimental locations had high PH (8.3 and 8.1) in the $1^{\text {st }}$ and $2^{\text {nd }}$ seasons, respectively). These results were agreeing with Khalilzadeh et al. (2012), who illustrated that foliar spray with extraction of cattle manure (10:1 distilled water) showed that the above ground plant measurements of mung bean as expressed by length, leaves and shoots number are influenced.

Data in Table (4) indicated that there was significant interaction effect between cultivars and PMT-N treatments on CGR values except at 130-160 days in the first season and the highest values were recorded from

the combination of SN-626 with $\mathrm{C} 1$ and $\mathrm{C} 4$ in the $1^{\text {st }}$ and $2^{\text {nd }}$ seasons, respectively.

\section{Root growth traits}

Data in Table (5) illustrated that the tested sugar beet cultivars differed significantly in root fresh weight, length and diameter, in both seasons, except the two NH-627 and Hercule cultivars of root diameter in the second season. Sugar beet SN-626 cultivar surpassed NH-627 and Hercule cultivars recording the highest values of these root growth traits in both seasons. Meantime, Hercule had the lowest values of root growth traits. These results may be referred to the differences among the evaluated cultivars in gene make-up. Differences among varieties were also reported by Abd El-Rahman et al. (2017).

The results indicated that sugar beet growth traits in Table (5) were markedly influenced by the studied PMT-N treatments in both seasons. Fertilizing beets with $(\mathrm{C} 1)$ resulted in the highest root fresh weight, followed by (C4), in SN-626 and Hercule variety in both seasons, while $\mathrm{C} 4$ treatment was the highest followed by $\mathrm{C} 1$ treatment of $\mathrm{NH}-627$ variety in two seasons. Applying $\mathrm{C} 1$ treatment also resulted in the highest root length and diameter in both seasons. 
Conversely, the lowest values of root growth traits were recorded by $\mathrm{C} 2$ treatment. Insignificant difference in root diameter between $\mathrm{NH}-627$ and Hercule varieties in the $2^{\text {nd }}$ season was noticed, also between $\mathrm{C} 4$ and $\mathrm{C} 3$ treatments of root length in $2^{\text {nd }}$ season and in root diameter in both seasons. These results were in agreement with those of Abd El-Rahman et al. (2017), who stated that two sprays with compost tea on sugar beet foliage led to increase in root weight and root dimensions.

Data in Table (5) manifest that the interaction between sugar beet cultivars and PMT-N treatments had insignificant effect on root weight in $1^{\text {st }}$ season and root dimensions in both seasons, while root fresh weight was significantly affected, in the $2^{\text {nd }}$ season only. The heaviest root fresh weight $(1085.0 \mathrm{~g})$ produced by fertilizing SN-626 variety with the recommended level (C1).

\section{Sugar beet yields}

\section{Root yield}

In respect to root yield, data in Table (6) revealed that the evaluated sugar beet varieties were substantially varied in root yield/fed in both seasons. The results cleared that SN-262 out-yielded NH-627 and Hercule

Table 5. Effects of the combinations of pigeon manure tea and mineral nitrogen (PMT-N) on root weight/plant (g), length and diameter $(\mathrm{cm})$ of three sugar beet cultivars

\begin{tabular}{|c|c|c|c|c|c|c|c|}
\hline \multirow[t]{2}{*}{ Cultivar } & \multirow{2}{*}{$\begin{array}{c}\text { PMT-N } \\
\text { combinations }\end{array}$} & \multicolumn{2}{|c|}{ Root weight/plant (g) } & \multicolumn{2}{|c|}{ Root length $(\mathrm{cm})$} & \multicolumn{2}{|c|}{ Root diameter (cm) } \\
\hline & & $2013 / 14$ & $2014 / 15$ & $2013 / 14$ & $2014 / 15$ & $2013 / 14$ & $2014 / 15$ \\
\hline \multirow{4}{*}{ SN-626 } & $\mathrm{C} 1$ & 1086.00 & 1085.00 & 28.83 & 30.6 & 11.47 & 10.25 \\
\hline & $\mathrm{C} 2$ & 873.00 & 839.00 & 25.00 & 27.23 & 10.23 & 10.10 \\
\hline & $\mathrm{C} 3$ & 950.33 & 910.33 & 26.50 & 28.63 & 10.73 & 10.40 \\
\hline & $\mathrm{C} 4$ & 1031.67 & 1029.00 & 27.40 & 29.07 & 10.90 & 10.37 \\
\hline \multicolumn{2}{|c|}{ Mean } & $951.67 \mathrm{a}$ & $926.11 \mathrm{a}$ & $26.93 \mathrm{a}$ & $26.93 \mathrm{a}$ & $10.83 \mathrm{a}$ & $10.44 \mathrm{a}$ \\
\hline \multirow{4}{*}{ NH-627 } & $\mathrm{C} 1$ & 1000.00 & 972.67 & 21.83 & 25.37 & 10.87 & 9.43 \\
\hline & $\mathrm{C} 2$ & 835.00 & 814.33 & 23.67 & 26.23 & 9.53 & 9.13 \\
\hline & $\mathrm{C} 3$ & 911.33 & 911.00 & 24.63 & 26.90 & 10.40 & 9.63 \\
\hline & $\mathrm{C} 4$ & 1034.67 & 1007.67 & 25.87 & 28.37 & 10.40 & 9.57 \\
\hline \multicolumn{2}{|c|}{ Mean } & $927.00 \mathrm{~b}$ & $911.00 \mathrm{~b}$ & $24.00 \mathrm{~b}$ & $24.00 \mathrm{~b}$ & $10.30 \mathrm{~b}$ & $9.61 \mathrm{~b}$ \\
\hline \multirow{4}{*}{ Hercule } & $\mathrm{C} 1$ & 975.33 & 967.33 & 19.70 & 22.93 & 10.63 & 9.43 \\
\hline & $\mathrm{C} 2$ & 820.67 & 808.67 & 21.53 & 24.10 & 9.43 & 9.17 \\
\hline & $\mathrm{C} 3$ & 903.00 & 896.33 & 22.13 & 23.72 & 10.10 & 9.50 \\
\hline & $\mathrm{C} 4$ & 926.67 & 900.00 & 23.67 & 24.87 & 10.10 & 9.67 \\
\hline \multicolumn{2}{|c|}{ Mean } & $883.44 \mathrm{c}$ & $868.33 \mathrm{c}$ & $21.76 \mathrm{c}$ & $21.76 \mathrm{c}$ & $10.06 \mathrm{c}$ & $9.63 \mathrm{~b}$ \\
\hline \multicolumn{2}{|c|}{ General Mean } & 920.70 & 901.81 & 24.23 & 26.50 & 10.40 & 9.89 \\
\hline \multicolumn{2}{|c|}{$\mathrm{C} 1$} & $1020.44 \mathrm{a}$ & $1008.33 \mathrm{a}$ & $26.12 \mathrm{a}$ & $27.94 \mathrm{a}$ & $10.99 \mathrm{a}$ & $10.39 \mathrm{a}$ \\
\hline \multicolumn{2}{|c|}{$\mathrm{C} 2$} & $842.89 \mathrm{~d}$ & $820.67 \mathrm{~d}$ & $22.18 \mathrm{~d}$ & $25.18 \mathrm{c}$ & $9.73 \mathrm{c}$ & $9.47 \mathrm{c}$ \\
\hline \multicolumn{2}{|c|}{$\mathrm{C} 3$} & $921.56 \mathrm{c}$ & $905.89 \mathrm{c}$ & $23.90 \mathrm{c}$ & $26.32 \mathrm{~b}$ & $10.41 \mathrm{~b}$ & $9.84 \mathrm{~b}$ \\
\hline \multicolumn{2}{|c|}{$\mathrm{C} 4$} & $997.67 \mathrm{~b}$ & $978.89 \mathrm{~b}$ & $24.72 \mathrm{~b}$ & $26.56 \mathrm{~b}$ & $10.47 \mathrm{~b}$ & $9.87 \mathrm{~b}$ \\
\hline \multicolumn{2}{|c|}{ LSD at $5 \%$ for cultivars (A) } & 0.71 & 0.57 & 0.52 & 0.47 & 0.19 & 0.13 \\
\hline \multicolumn{2}{|c|}{ LSD at $5 \%$ for PMT-N (B) } & 0.95 & 0.60 & 0.29 & 0.29 & 0.20 & 0.14 \\
\hline \multicolumn{2}{|c|}{$\mathrm{LSD}$ at $5 \%$ for $\mathrm{AB}$} & Ns & 1.45 & Ns & Ns & Ns & Ns \\
\hline
\end{tabular}

by 1.1 and 1.97 ton of roots/fed, in the $1^{\text {st }}$ season, corresponding to 1.09 and 1.82 ton/fed in the $2^{\text {nd }}$ one, respectively. These results may be attributed to the superiority of SN-262 over NH-627 and Hercule varieties in root fresh weight (Table 6). Varietal difference in root yield was also reported by Khalilzadeh et al. (2012) and Abd El-Rahman et al. (2017).

The results elucidated that the application of $(\mathrm{C} 1)$ resulted in the highest root yield, recording gradual increases of 1.28, 2.76 and 4.73 ton/fed higher than that obtained from beets fertilized with $\mathrm{C} 4, \mathrm{C} 3$ and $\mathrm{C} 2$, respectively, in the $1^{\text {st }}$ season, and $2.13,2.85$ and 4.98 ton/fed, respectively in the $2^{\text {nd }}$ one. These results are probably due to similar trend of the single root fresh weight as affected by PMT-N treatments, in the same sequence (Table, 6). On the other hand, the data illustrated that increasing the concentration of PMT from $\mathrm{C} 2$ to $\mathrm{C} 4$ combinations led to increases in root yield/fed amounted to (3.96 and 4.75 ton), (3.72 and 3.56 ton) and (2.65 and 2.28 ton) in $1^{\text {st }}$ and $2^{\text {nd }}$ season of each of SN-626, NH-627 and Hercule variety, respectively. These results are in line with those mentioned in Egypt by Abd El-Rahman et al. (2017), 
who stated that foliar application of sugar beet varieties with compost tea at the rate of $20 \mathrm{~L} /$ fed resulted in higher root yield compared to check treatment. Moreover, significant difference was found between $\mathrm{C} 1$ and $\mathrm{C} 2$ as well as between $\mathrm{C} 3$ and $\mathrm{C} 4$ in their effect on the obtained root yield/fed in both seasons.

Root yield was appreciably influenced by the interaction between the studied factors in the $2^{\text {nd }}$ season only (Table 6). Also, distinguished positive increase in root yield was gained by $\mathrm{C} 4$ compared with $\mathrm{C} 2$ and $\mathrm{C} 3$ treatments in both seasons.

\section{Top yield}

Data in Table (6) showed that there were significant differences among the tested cultivars. Where, the highest top yield was recorded by SN-626 cultivar followed by NH-627 with significant difference. On the other hand, the lowest top yield was produced from Hercule cultivar which differed significantly from $\mathrm{NH}-$ 627 in the $1^{\text {st }}$ season only. These results were agreed with Abd El-Rahman et al (2017).

The results showed that top yield was positively affected by PMT-N treatments in both seasons. Where, the highest top yield was recorded by $\mathrm{C} 1$ treatment (16.21 and 16 ton/fed) followed by C4 (15.42 and 15.21 ton/fed) with significant difference in $1^{\text {st }}$ and $2^{\text {nd }}$ seasons, respectively, while the lowest top yield was recorded from C2 treatment (13.78 and 13.47 ton/fed) in $1^{\text {st }}$ and $2^{\text {nd }}$ seasons, respectively. Data indicated also that increasing PMT concentration from 2.5 to $10 \%$ led to increase in top yield by 1.64 and 1.74 ton in $1^{\text {st }}$ and $2^{\text {nd }}$ seasons, respectively. These results were agreed with that reported by Abd El-Rahman et al. (2017).

Top yield was insignificantly affected by the interaction between tested cultivars and PMT-N treatments in both seasons (Table, 6).

\section{Sugar yield}

Data in Table (6) showed that there were significant differences among the three tested sugar beet cultivars. Where, the highest sugar yield/fed was recorded by SN626 cultivar in both seasons. By contrast, the lowest sugar yield/fed was produced by Hercule cultivar in both seasons. These results were in line with Abd ElRahman et al. (2017).

Table 6. Effects of the combinations of pigeon manure tea and mineral nitrogen (PMT-N) on root, top and sugar yields/fed (ton) of the three sugar beet cultivar

\begin{tabular}{|c|c|c|c|c|c|c|c|}
\hline \multirow[t]{2}{*}{ Cultivar } & \multirow{2}{*}{$\begin{array}{c}\text { PMT-N } \\
\text { combinations }\end{array}$} & \multicolumn{2}{|c|}{ Root yield/fed (ton) } & \multicolumn{2}{|c|}{ Top yield/fed (ton) } & \multicolumn{2}{|c|}{ Sugar yield/fed (ton) } \\
\hline & & 2013/14 & $2014 / 15$ & $2013 / 14$ & $2014 / 15$ & 2013/14 & $2014 / 15$ \\
\hline \multirow{4}{*}{ SN-626 } & $\mathrm{C} 1$ & 27.15 & 27.13 & 17.58 & 15.09 & 4.64 & 4.01 \\
\hline & $\mathrm{C} 2$ & 21.83 & 20.98 & 14.93 & 14.38 & 4.03 & 3.78 \\
\hline & $\mathrm{C} 3$ & 23.76 & 22.76 & 15.88 & 15.54 & 4.19 & 3.96 \\
\hline & $\mathrm{C} 4$ & 25.79 & 25.73 & 16.71 & 15.83 & 4.26 & 4.08 \\
\hline \multicolumn{2}{|r|}{ Mean } & $24.63 \mathrm{a}$ & $24.15 \mathrm{a}$ & $16.28 \mathrm{a}$ & $15.61 \mathrm{a}$ & $4.28 \mathrm{a}$ & $4.08 \mathrm{a}$ \\
\hline \multirow{4}{*}{ NH-627 } & $\mathrm{C} 1$ & 25.87 & 25.19 & 15.92 & 13.93 & 4.30 & 3.77 \\
\hline & $\mathrm{C} 2$ & 20.88 & 20.36 & 13.42 & 13.08 & 3.88 & 3.57 \\
\hline & $\mathrm{C} 3$ & 22.78 & 22.78 & 14.54 & 14.08 & 3.97 & 3.73 \\
\hline & $\mathrm{C} 4$ & 24.60 & 23.92 & 15.17 & 14.92 & 4.04 & 3.82 \\
\hline & Mean & $23.53 \mathrm{~b}$ & $23.06 \mathrm{~b}$ & $14.76 \mathrm{~b}$ & $14.44 \mathrm{~b}$ & $4.05 \mathrm{~b}$ & $3.81 \mathrm{~b}$ \\
\hline \multirow{4}{*}{ Hercule } & $\mathrm{C} 1$ & 24.38 & 24.18 & 15.13 & 13.90 & 4.02 & 3.57 \\
\hline & $\mathrm{C} 2$ & 20.52 & 20.22 & 13.00 & 12.96 & 3.62 & 3.14 \\
\hline & $\mathrm{C} 3$ & 22.58 & 22.41 & 14.13 & 14.33 & 3.79 & 3.52 \\
\hline & $\mathrm{C} 4$ & 23.17 & 22.50 & 14.38 & 14.88 & 3.95 & 3.71 \\
\hline \multicolumn{2}{|c|}{ Mean } & $22.66 \mathrm{c}$ & $22.33 \mathrm{c}$ & $14.16 \mathrm{c}$ & $14.45 \mathrm{~b}$ & $3.84 \mathrm{c}$ & $3.64 \mathrm{c}$ \\
\hline \multicolumn{2}{|c|}{ General Mean } & 23.61 & 23.18 & 15.06 & 14.83 & 4.06 & 3.84 \\
\hline \multicolumn{2}{|c|}{$\mathrm{C} 1$} & $25.80 \mathrm{a}$ & $25.50 \mathrm{a}$ & $16.21 \mathrm{a}$ & $16.00 \mathrm{a}$ & $4.32 \mathrm{a}$ & $4.17 \mathrm{a}$ \\
\hline \multicolumn{2}{|r|}{$\mathrm{C} 2$} & $21.07 \mathrm{~d}$ & $20.52 \mathrm{~d}$ & $13.78 \mathrm{~d}$ & $13.47 \mathrm{~d}$ & $3.90 \mathrm{~b}$ & $3.62 \mathrm{c}$ \\
\hline \multicolumn{2}{|r|}{$\mathrm{C} 3$} & $23.04 \mathrm{c}$ & $22.65 \mathrm{c}$ & $14.85 \mathrm{c}$ & $14.65 \mathrm{c}$ & $3.93 \mathrm{~b}$ & $3.65 \mathrm{c}$ \\
\hline \multicolumn{2}{|c|}{$\mathrm{C} 4$} & $24.52 \mathrm{~b}$ & $23.37 \mathrm{~b}$ & $15.42 \mathrm{~b}$ & $15.21 \mathrm{~b}$ & $4.08 \mathrm{~b}$ & $3.83 \mathrm{~b}$ \\
\hline \multicolumn{2}{|c|}{ LSD at $5 \%$ for cultivars (A) } & 0.71 & 0.57 & 0.52 & 0.47 & 0.19 & 0.13 \\
\hline \multicolumn{2}{|c|}{ LSD at $5 \%$ for PMT-N (B) } & 0.95 & 0.60 & 0.29 & 0.29 & 0.20 & 0.14 \\
\hline \multicolumn{2}{|c|}{$\mathrm{LSD}$ at $5 \%$ for $\mathrm{AB}$} & Ns & 1.45 & Ns & Ns & Ns & Ns \\
\hline $\begin{array}{l}\text { C1: } 80 \mathrm{~kg} \mathrm{~N} / \mathrm{fe} \\
\text { C2: } 40 \mathrm{~kg} \mathrm{~N} / \mathrm{fe}\end{array}$ & $\begin{array}{l}\text { (recommended lev } \\
+ \text { PMT at } 2.5 \%\end{array}$ & PMT (c) & ment) & $\begin{array}{l}\text { C3: } 40 \mathrm{~kg} \\
\text { C4: } 40 \mathrm{~kg}\end{array}$ & $\begin{array}{l}\text { PMT at } 5 \\
\text { PMT at } 1\end{array}$ & & \\
\hline
\end{tabular}


Results illustrated that sugar yield was clearly affected by PMT-N treatments in both season. Treated sugar beet plants with recommended $\mathrm{N}$ level produced the highest sugar yield/fed in both seasons. On the other hand, data showed that $\mathrm{C} 4$ resulted in higher sugar yield ton/fed (4.08 and 3.83) than C3 (3.93 and 3.65) with significant difference in $2^{\text {nd }}$ season only. But treated beets with $\mathrm{C} 2$ produced the lowest sugar yield/fed with no significant difference from $\mathrm{C} 3$ in both seasons. On the other hand, the results showed that sugar yield/fed produced by SN-626, NH-627 and Hercule was increased by ( 0.23 and 0.3 ton), ( 0.16 and 0.25 ton) and ( 0.33 and 0.57 ton) as a result of increasing the concentration of PMT from $\mathrm{C} 2$ to $\mathrm{C} 4$ combinations, in the $1^{\text {st }}$ and $2^{\text {nd }}$ season, respectively.

These results were in harmony with Abd El-Rahman et al. (2017) who stated that foliar application of sugar beet varieties with compost tea at the rate of $20 \mathrm{~L} / \mathrm{fed}$ resulted in higher sugar yield compared to check treatment.

Sugar yield was insignificantly affected by the interaction between tested cultivars and PMT-N treatments in both seasons (Table 6). There were increase in sugar yield/fed was observed when the SN626 was applied by increasing the concentration of PMT from $2.5 \%$ to $10 \%$ with $40 \mathrm{~kg} \mathrm{~N} / \mathrm{fed}$ in both seasons, however the application of Hercule with any treatment of $\mathrm{C} 2, \mathrm{C} 3$ and $\mathrm{C} 4$ resulted in increase in sugar yield. On the other hand, the data reflected that $\mathrm{C} 4$ treatment was higher in sugar yield than $\mathrm{C} 1$ in all different varieties in $2^{\text {nd }}$ season only.

\section{Sugar quality traits}

Data in Table (7) illustrated that the tested beet varieties were significantly differed in sucrose $\%$ in both seasons. Where, the highest sucrose $\%$ was produced by SN-626 (17.42\% and $16.95 \%)$ in $1^{\text {st }}$ and $2^{\text {nd }}$ seasons, respectively, with no significant difference with $\mathrm{NH}$ 627 in the $1^{\text {st }}$ season only. On the other hand, the lowest sucrose $\%$ was recorded by Hercule $(17.02 \%$ and $16.36 \%)$ in $1^{\text {st }}$ and $2^{\text {nd }}$ seasons, respectively, with no significant difference with $\mathrm{NH}-627$ in the $1^{\text {st }}$ season only. Similar findings were reported by Abd El-Rahman et al. (2017).

Table 7. Effects of the combinations of pigeon manure tea and mineral nitrogen (PMT-N) on TSS\%, sucrose \% and purity \% of three sugar beet cultivars

\begin{tabular}{|c|c|c|c|c|c|c|c|}
\hline \multirow[t]{2}{*}{ Cultivar } & \multirow{2}{*}{$\begin{array}{c}\text { PMT-N } \\
\text { combinations }\end{array}$} & \multicolumn{2}{|c|}{ TSS\% } & \multicolumn{2}{|c|}{ Sucrose \% } & \multicolumn{2}{|c|}{ Purity \% } \\
\hline & & $2013 / 14$ & $2014 / 15$ & 2013/14 & $2014 / 15$ & $2013 / 14$ & $2014 / 15$ \\
\hline \multirow{4}{*}{ SN-626 } & $\mathrm{C} 1$ & 23.50 & 23.33 & 16.47 & 16.00 & 75.08 & 73.94 \\
\hline & $\mathrm{C} 2$ & 24.33 & 24.33 & 17.91 & 17.40 & 83.59 & 82.16 \\
\hline & $\mathrm{C} 3$ & 24.00 & 24.00 & 17.07 & 16.55 & 79.63 & 77.51 \\
\hline & $\mathrm{C} 4$ & 23.16 & 23.00 & 16.23 & 15.86 & 75.16 & 73.06 \\
\hline \multicolumn{2}{|c|}{ Mean } & 23.75 & 23.67 & $17.42 \mathrm{a}$ & $16.95 \mathrm{a}$ & 78.37 & 76.67 \\
\hline \multirow{4}{*}{ NH-627 } & $\mathrm{C} 1$ & 23.17 & 23.33 & 17.00 & 15.54 & 71.97 & 69.94 \\
\hline & $\mathrm{C} 2$ & 25.17 & 25.17 & 17.73 & 16.79 & 87.03 & 80.21 \\
\hline & $\mathrm{C} 3$ & 24.33 & 24.33 & 16.62 & 16.35 & 77.85 & 74.02 \\
\hline & $\mathrm{C} 4$ & 23.90 & 24.00 & 15.77 & 15.59 & 70.04 & 69.99 \\
\hline \multicolumn{2}{|c|}{ Mean } & 24.14 & 24.21 & $17.28 \mathrm{ab}$ & $16.57 \mathrm{~b}$ & 76.72 & 73.54 \\
\hline \multirow{4}{*}{ Hercule } & $\mathrm{C} 1$ & 23.17 & 23.33 & 16.47 & 15.42 & 70.95 & 70.06 \\
\hline & $\mathrm{C} 2$ & 25.00 & 24.83 & 17.49 & 16.55 & 84.95 & 79.93 \\
\hline & $\mathrm{C} 3$ & 24.17 & 24.17 & 16.47 & 16.11 & 77.56 & 73.83 \\
\hline & $\mathrm{C} 4$ & 23.73 & 23.67 & 15.64 & 15.35 & 70.96 & 70.05 \\
\hline \multicolumn{2}{|c|}{ Mean } & 24.02 & 24.00 & $17.02 \mathrm{~b}$ & $16.36 \mathrm{c}$ & 76.11 & 73.47 \\
\hline \multicolumn{2}{|c|}{ General Mean } & 23.97 & 23.96 & 17.24 & 16.63 & 77.07 & 74.56 \\
\hline \multicolumn{2}{|c|}{$\mathrm{C} 1$} & $23.28 \mathrm{bc}$ & $23.33 \mathrm{~b}$ & $16.65 \mathrm{~b}$ & $15.65 \mathrm{c}$ & $72.34 \mathrm{c}$ & $71.31 \mathrm{c}$ \\
\hline \multicolumn{2}{|c|}{$\mathrm{C} 2$} & $24.17 \mathrm{a}$ & $24.17 \mathrm{a}$ & $17.72 \mathrm{a}$ & $17.34 \mathrm{a}$ & $85.19 \mathrm{a}$ & $80.77 \mathrm{a}$ \\
\hline \multicolumn{2}{|c|}{$\mathrm{C} 3$} & $23.83 \mathrm{~b}$ & $23.78 \mathrm{~b}$ & $16.88 \mathrm{~b}$ & $16.60 \mathrm{~b}$ & $78.35 \mathrm{~b}$ & $75.12 \mathrm{~b}$ \\
\hline \multicolumn{2}{|c|}{$\mathrm{C} 4$} & $23.60 \mathrm{~b}$ & $23.56 \mathrm{~b}$ & $15.71 \mathrm{c}$ & $15.92 \mathrm{c}$ & $72.39 \mathrm{c}$ & $71.03 \mathrm{c}$ \\
\hline \multicolumn{2}{|c|}{ LSD at $5 \%$ for cultivars (A) } & $\mathrm{Ns}$ & Ns & 0.28 & 0.14 & $\mathrm{Ns}$ & $\mathrm{Ns}$ \\
\hline \multicolumn{2}{|c|}{ LSD at $5 \%$ for PMT-N (B) } & 0.39 & 0.46 & 0.28 & 0.51 & 1.14 & 1.49 \\
\hline \multicolumn{2}{|c|}{$\mathrm{LSD}$ at $5 \%$ for $\mathrm{AB}$} & $\mathrm{Ns}$ & $\mathrm{Ns}$ & $\mathrm{Ns}$ & $\mathrm{Ns}$ & 1.97 & 3.59 \\
\hline
\end{tabular}


Data indicated also that PMT-N treatments significantly increased TSS\% and sucrose $\%$, however, it significantly increased purity $\%$ compared to $\mathrm{C} 1$ treatment in both seasons. Where, the highest values of TSS $\%$, sucrose $\%$ and purity $\%$ were recorded by $\mathrm{C} 2$ treatment in both seasons. On the other hand, the lowest values of the previous traits were generally recorded by $\mathrm{C} 4$ and $\mathrm{C} 1$ treatments in both seasons. Similar observations were reported by Fayek et al. (2014) who illustrated that spraying Keitte mango trees three times with tea of chicken manure $10 \%$ extract was significantly very effective in improving T.S.S. \% relative to the check treatment. Similar findings were reported with regard to sucrose\% by Abd El-Rahman et al. (2017) who stated that foliar spray with compost tea at level $20 \mathrm{~L} / \mathrm{fed}$ resulted in significant increases in sucrose \% compared to check treatment. In addition, the same results were reported by Abd El-Rahman et al. (2017) with regard to purity\%, who stated that foliar spray with compost tea at level $20 \mathrm{~L} / \mathrm{fed}$ resulted significant increases in purity\% compared to check treatment.

In regard to the interaction between beet varieties and PMT-N treatments (Table, 7), there were insignificant interaction effects on the tested sugar quality traits except on purity\% in both seasons.

\section{Genetic parameters}

Genotypic variance, genotypic coefficient of variability, phenotypic variance, phenotypic coefficient of variability, environmental variance and broad sense heritability for seven recorded traits were shown in Table (8).

\section{Genotypic and phenotypic variance}

Purity $\%$ exhibited the highest genotypic and phenotypic variance, i.e 1.28 and 12.27 , respectively, followed by the root yield that have genotypic variance 0.524 and phenotypic variance 1.101 and top yield that gave 0.649 in genotypic variance and 0.758 in phenotypic variance. On the other hand, the lowest

Table 8. Genotypic, phenotypic variance and coefficient of variability and broad sense heritability

\begin{tabular}{|c|c|c|c|c|c|c|}
\hline \multirow[b]{2}{*}{ Characters } & \multirow{2}{*}{$\begin{array}{c}\sigma^{2} \mathrm{e} \\
\text { Environmental } \\
\text { variance }\end{array}$} & \multirow{2}{*}{$\begin{array}{c}\sigma^{2} \mathrm{~g} \\
\text { Genotypic } \\
\text { variance }\end{array}$} & \multirow{2}{*}{$\begin{array}{c}\sigma^{2} p \\
\text { Phenotypic } \\
\text { variance }\end{array}$} & \multirow{2}{*}{$\begin{array}{c}\text { Broad sense } \\
\text { heritability } \\
\left(\mathbf{H}^{2} \mathbf{b} \%\right)\end{array}$} & \multicolumn{2}{|c|}{ Coefficient of variability } \\
\hline & & & & & $\begin{array}{c}\text { Genotypic } \\
\text { (GCV \%) }\end{array}$ & $\begin{array}{c}\text { Phenotypic } \\
\text { (PCV \%) }\end{array}$ \\
\hline Root Diameter & 0.026 & 0.182 & 0.208 & 87.50 & 4.297 & 4.588 \\
\hline Root Yield & 0.577 & 0.524 & 1.101 & 47.59 & 7.687 & 8.925 \\
\hline Top yield & 0.109 & 0.649 & 0.758 & 85.62 & 5.583 & 6.034 \\
\hline Sugar yield & 0.036 & 0.038 & 0.072 & 52.77 & 4.969 & 6.892 \\
\hline Sucrose $\%$ & 0.06 & 0.06 & 0.12 & 50.00 & 1.43 & 2.01 \\
\hline TSS $\%$ & 0.96 & 0.03 & 0.99 & 3.03 & 0.63 & 4.20 \\
\hline Purity $\%$ & 10.99 & 1.28 & 12.27 & 10.43 & 1.54 & 4.76 \\
\hline
\end{tabular}

genotypic and phenotypic variance was recorded for the traits of sugar yield and sucrose $\%$ i.e. $0.038 \& 0.073$ for sugar yield and $0.06 \& 0.12$ for the Sucrose\%, respectively. On the contrary, these results differed partly with MacLachlan (1972), who mentioned that large amounts of genetic variance were found for root and sugar yield and for sugar content, as well as for other characters.

\section{Coefficient of variability}

The coefficient of phenotypic and genotypic variance values were, also calculated for all the traits under study. The genotypic coefficient of variability was ranged from 0.63 for TSS\% to 7.687 for root yield. Maximum genotypic coefficient of variation was observed for the root yield (7.687) followed by top yield (5.583). Phenotypic coefficient of variability almost had similar trend as genotypic coefficient of variability. In the present study there was a close correspondence between genotypic and phenotypic coefficient of variability for most the recorded traits. It showed that these characters were less influenced by the environment. The highest genotypic and phenotypic coefficient of variability observed for the root yield followed by top yield and sugar yield. It indicates that selection can be applied on these traits in countries which have optimal conditions for sugar beet breeding programs. Sklenar et al (1998) also noticed the moderate phenotypic and genotypic coefficient of variability for some traits and suggested that these characters can be improved by the vigorous selection. Similar type of observations was also reported by Tadesse and Dilnesaw (2014).

The traits such as sucrose $\%$, TSS $\%$ and purity $\%$ exhibited low PCV and GCV which indicated that the breeders should increase the variability for these traits to achieve improvement. Similar type of suggestion was given by Agrawal and Kumar (2017) in their experiments. 


\section{Broad sense heritability}

Genotypic coefficient of variations is not a correct measure to determine the heritable variation present and should be considered together with heritability estimates. In the present experiment, low to high heritability estimates were noticed for all the characters studied (Table 8). Similar results were also reported by Ganapati et al. (2015). Maximum heritability values were obtained by root diameter $(87.50 \%)$ followed by top yield $(85.62 \%)$. It was moderate for sugar yield $(52.77 \%)$, sucrose $\%(50.00 \%)$ and root yield $(47.59 \%)$. While TSS\% gave value $3.03 \%$ and purity was $10.43 \%$. Thus both reported very low heritability values. Also these results are partly consistent with Geidel et al. (2000) which suggested that the heritability for sugar content is always greater than that of root yield. Swamy Gowda et al. (2016) reported that low heritability coupled with low GCV, PCV as percent suggesting selection will be less effective for this trait. The results of the present study exhibited high genetic variability and high range of variations. However, the differences between PCV and GCV were indicating environmental influence value in the expression of these characters studied.

\section{Correlation}

Results in Table (9) showed matrices of simple correlation coefficients between the studied sugar beet characters. Sugar yield (ton/fed) was strongly positively correlated with root yield ton/fed in SN-626 and NH627 varieties which were $0.87^{* *}$ and $0.71^{* *}$ respectively, while it was $0.53^{*}$ in Hercule variety. The correlation coefficient values between sugar yield (ton/fed) and sucrose $\%$ were $0.46^{*}, 0.69^{* *}$ and $0.50^{*}$ for SN-626, NH627 and Hercule varieties, respectively. These results indicated that sugar yield was highly influenced with sucrose \% in NH-627 variety. As well as correlation values between sugar yield ton/fed and Purity\% ranged from $0.55^{*}$ to $0.44^{*}$ in NH-627 and SN-626 varieties, respectively.

Negative correlation was detected between root yield (ton/fed) and each of sucrose $\%$ and Purity $\%$ in all varieties. Similar observations were found by Geidel et al. (2000), who reported that the correlation coefficients between sugar content and root yield are, as expected, negative but there are some exceptions. As well Nasri et al. (2012) illustrated that root yield had negative correlation with net and gross sugar percentage.

Furthermore, strongly positive correlation was found between Sucrose\% and Purity\% which was 0.93, 0.95 and 0.87 in SN-626, NH-627 and Hercule varieties, respectively. These results were in accordance with those reported by MacLachlan (1972) and Moosavi et al (2017).

\section{Path-coefficient}

Analyses of Path-coefficient for sugar yield using the three yield components are presented in Table (10). The relative effect of the characters under study on sugar yield for three varieties is presented by the direct effect component of the partitioning total correlations. The direct effect measures the association of sugar yield with each character with the other variables held constant.

Table 9. Simple correlation matrix between some variables of three Varieties

\begin{tabular}{|c|c|c|c|}
\hline \multicolumn{4}{|c|}{ SN-626 } \\
\hline Variable & Sugar yield ton/fed & Root yield ton/fed & Sucrose $\%$ \\
\hline Sugar yield ton/fed & - & - & 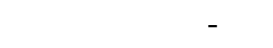 \\
\hline Root yield ton/fed & $0.87 * *$ & - & - \\
\hline Sucrose $\%$ & $0.46 *$ & $-0.30 *$ & - \\
\hline Purity \% & $0,44 *$ & $-0.29 *$ & $0.93 * *$ \\
\hline \multicolumn{4}{|c|}{ NH-627 } \\
\hline Variable & Sugar yield ton/fed & Root yield ton/fed & Sucrose $\%$ \\
\hline Sugar yield ton/fed & - & - & - \\
\hline Root yield ton/fed & $0.71 * *$ & - & - \\
\hline Sucrose \% & $0.69 * *$ & $-0.27 *$ & - \\
\hline Purity \% & $0.55 *$ & $-0.32 *$ & $0.95 * *$ \\
\hline \multicolumn{4}{|c|}{ Hercule } \\
\hline Variable & Sugar yield ton/fed & Root yield ton/fed & Sucrose $\%$ \\
\hline Sugar yield ton/fed & - & - & - \\
\hline Root yield ton/fed & $0.53 *$ & - & - \\
\hline Sucrose \% & $0.50 *$ & -0.17 & - \\
\hline Purity \% & $0.47 *$ & -0.19 & $0.87 * *$ \\
\hline
\end{tabular}

Correlation coefficient at the 0.05 and 0.01 levels of significance 
Table 10. The total correlations (r) and partitioning total correlation path values from the path- coefficient analyses of sugar yield per unit weight vs. three components of yield of three varieties

\begin{tabular}{lccc}
\hline \multirow{2}{*}{ Character analyzed } & \multicolumn{2}{c}{ Varieties } & Hercule \\
\cline { 2 - 4 } & SN-626 & NH-627 & 0.615 \\
Direct effect & Sugar yield vs Root yield & & -0.020 \\
Indirect effect via sucrose \% & 0.991 & 0.883 & -0.080 \\
Indirect effect via purity \% & -0.125 & -0.091 & 0.515 \\
Total correlation & -0.138 & -0.216 & 0.459 \\
& 0.728 & 0.576 & -0.033 \\
Direct effect & Sugar yield vs Sucrose \% & 0.087 \\
Indirect effect via Root yield & 0.513 & 0.510 & 0.513 \\
Indirect effect via purity \% & -0.216 & -0.115 & 0.292 \\
Total correlation & 0.129 & 0.687 & 0.451 \\
& 0.426 & & -0.144 \\
Direct effect & Sugar yield vs Purity \% & 0.589 & 0.210 \\
Indirect effect via Root yield & 0.466 & -0.250 & 0.517 \\
Indirect effect via sucrose \% & -0.218 & 0.217 & 0.556 \\
Total correlation & 0.121 & 0.369 & \\
\hline
\end{tabular}

In the SN-626 variety, root yield was more important than sucrose\% and over twice as important as purity $\%$ in determining sugar yield. However, in the NH-627 and Hercule varieties, the relative importance of both sucrose $\%$ and purity $\%$ in determining sugar yield was increased. The relative importance of purity\% approached that of root yield in Hercule variety $(0.451$ vs. 0.615$)$ also the direct effects of sucrose $\%(0.459)$ and purity\% (0.451) were essentially equal. Hence, it appears that different genotypes can alter the relative importance of characters that determine sugar yield. The obtained findings are in harmony with Firouzabadi et al. (2011) who found that the sequential path analysis efficiently demonstrated the effects of predictor variables.

The influence of each independent variable on sugar yield due to association with the other independent variables in the system is shown by the indirect components in the partitioning of the observed total correlation. In the SN-626 variety, the total correlation for sugar yield vs. root weight, 0.728, is composed of the direct effect of root weight, 0.991, and the indirect effects of root weight and its negative association with sucrose $\%,-0.125$, and purity $\%,-0.138$. The same was observed in the other two varieties. In the partitioning of the total correlation between sugar yield and sucrose\% for the SN-626 variety, the negative association of root weight and sucrose $\%$ is reflected in the rather large negative indirect effects via root weight and sucrose (- 0.216 and - 0.125). These results are in agreement with Moosavi et al. (2017), who studied path analysis for root yield of sugar beet under different levels of drought stress.
In the three varieties the negative association of purity $\%$ and root weight is shown by the large negative indirect effects of root weight and purity \% (- 0.218, 0.250 and - 0.144) for SN-626, NH-627 and Hercule varieties, respectively in the partitioning of the total correlation between sugar yield and purity $\%$.

In general, the data showed that root weight was the most important component of sugar yield, followed by sucrose $\%$ and purity\% in SN-626 variety. Of more significance was the fact that the relative importance of purity $\%$ and sucrose $\%$ was increased in NH-627 and Hercule varieties. Also sucrose $\%$ ranked first in importance in the NH-627 variety as a determine of sugar yield in the path-coefficient analyses. The data demonstrated that further progress with these improved genotypes would best be realized by increased emphasis on sucrose $\%$ and purity $\%$.

Presently, sugar beet breeders are working firstly with improved varieties. The evidence presented in this study illustrates the change in relative importance of characters in different varieties can take place with breeding improvements in countries which have optimal conditions for sugar beet breeding programs. A compromise of maximum root yield may be necessary to achieve significant increases in sugar yield.

The data suggests that significant improve could be possible by more effort on purity $\%$ as well as sucrose $\%$. The obtained results are in accordance with Bhagowati and Saikia (2003), who suggested that in path analysis, the variables that are most effective on dependent variable are being considered as the first-order predictors of response variable that is mainly yield in agricultural studies, however in places where the independent variables have correlation with each other. 


\section{CONCLUSION}

Generally, all traits of SN-626 surpassed improving achieved by the other two cultivars followed by $\mathrm{NH}-$ 627 and the last one was Hercule. For comparing between $\mathrm{C} 4$ and $\mathrm{C} 1$ treatments, $\mathrm{C} 4$ was not significantly different than C1 for CGR130-160 days, CGR160-190 days, TSS $\%$, sucrose $\%$ and purity $\%$ characters. As well as $\mathrm{C} 4$ was higher than $\mathrm{C} 1$ treatment in sugar yield characters only in $2^{\text {nd }}$ season in the three cultivars under study. In the present experiment, low to high heritability estimates were noticed for all the characters studied. The results of the present study exhibited high genetic variability and high range of variations among the three studied varieties. However, the differences between PCV and GCV were indicating environmental influence value in the expression of these characters studied. The data suggests that significant improve could be possible by more effort on purity as well as sucrose percentages to increase sugar yield as much as possible.

\section{REFERENCES}

Abd El-Rahman, M.M., A.A. Abo El-Ftooh and M.A. Ghonema. 2017. Response of some sugar beet varieties to foliar spraying with compost tea and its relationship with two sugar beet insects, beet fly (Pegomya mixta Vill.) and tortoise beetle (Cassida vittata Vill.) under newly reclaimed sandy soil. Menoufia J. Pl. Prod., 2: 53-63.

Agrawal, R.K. and B. Kumar. 2017. Variability, heritability and genetic advance for cane yield and its contributing traits in sugarcane clones under waterlogged condition. Int. J. Cur. Micro. App. Sci., 6(6): 1669-1679.

Ajmera, S., S.S. Kumar and V. Ravindrababu. 2017. Evaluation of genetic variability, heritability and genetic advance for yield and yield components in rice genotypes. Int. J. Cur. Micro. Appl. Sci., 6(10): 1657-1664.

Akl, A.M.M.A., H.H.M. Saied and A.Sh. Hassan. 2017. Impact of using chicken manure tea and ascorbic acid as substitutes for mineral $\mathrm{N}$ fertilizer on fruiting of superior grapevines. Assiut J. Agric. Sci., 48 (3): 160-171.

Allard, R.W. 1999. Principles of Plant Breeding. $2^{\text {nd }}$ edition, John Wiley and Sons Inc. New York, USA, Pp 264.

Bhagowati, R.R. and M. Saikia. 2003. Character association and path coefficient analysis for yield attributes in open pollinated and hybrid true potato seed populations. Crop Res. 26:286-290.

Black, G.R. 1965. "Methods of Soil Analysis" Part II: Agron. Series, (9) U.S.A.

Burton, G.W. 1952. Quantitative Inheritance In Grasses. Proceedings of $6^{\text {th }}$ International Grassland Congress, 1: 277-283.

Diver, S. 2002. Notes on compost teas: A supplement to the ATTRA Publication "Compost Teas for Plant Disease Control", Pest Management Technical Note ATTRA \& NCAT.
Falconer, D. S. 1964. Introduction to Quantitative Genetics. Longmann. pp. 294-300.

Fayek, M. A., T.A. Fayed, E.M. Fakhrani and N.S. Shaymmaa (2014). Yield and fruit quality of "Le-conte" pear trees as affected by compost tea and some antioxidants applications. J. Hort. Sci. \& Ornamental Pl. 6 (1):1-8.

Firouzabadi, M.B., N. Farrokhi and M. Parsaeyan (2011). Sequential path analysis of some yield and quality components in sugar beet grown in normal and drought conditions. Ital. J. Agron., 6: (4) 45-51.

Ganapati, R.K., R. Rani, K.M.R. Karim, R.K. Roy and M.M. Rahman. 2015. Variability, heritability and genetic advance of quantitative traits in sugar beet (Beta vulgaris L.) by effect of mutation. Int. J. Pl. Biol. Res., 3(4): 1046.

Gharib,H.S. and A.S.EL-Henawy. 2011. Response of sugar beet (Beta Vulgaris,L.) to irrigation regine, nitrogen rate and micronutrients application.Alex. Sci. Exch. J.32:140-156.

Geidel, H., W.E. Weber, W. Mechelke and W. Haufe. 2000. Selection for sugar yield in sugar beet, Beta vulgaris, using different selection indices. Pl. Breed., 119: 188-190.

Haggag, F. Laila, M.F.M. Shahin, H.A. Mahdy, Amira K.G. Atteya and H.S.A. Hassan. 2015. Beneficial effect of NPK, pigeon manure tea and microbial fertilizers as soil application on growth of "Toffahi" and "Picual" olive seedlings. J. Agric. Tech., 11(7): 1565-1582.

Ilkaee, M.N., Z. Babaei, A. Baghdadi and F. Golzardi. 2016. Effect of different planting dates and defoliation on the properties of sugar beet (Beta vulgaris L.). J. Exp. Bio. Agric. Sci., 4(1): 52-58.

Ingham, E.R. 2005. The Compost Tea Brewing Manual; Latest Methods and Research. $5^{\text {th }}$ Edn. Soil Food Web Inc., Corvallis, OR.

Johnson, H.W., H.F Robinson and R.E. Comstock. 1955. Estimates of genetic and environmental variability in soybean. Agron. J., 47 (7): 314-318.

Khalilzadeh, R., M. Tajbakhsh and J. Jalilian. 2012. Growth characteristics of mung bean (Vigna radiata L.) affected by foliar application of urea and bio-organic fertilizers. Intl. J. Agri. Crop Sci., 4 (10): 637-642.

Le-Docte, A. 1927. Commercial determination of sugar in the beet root using the Sacks- Le Docte process, Int. Ug. J., 29: 488-492.

Li, C.C. 1956. The concept of path coefficient and its impact on population genetics. Biometrics, 12:190-210.

MacLachlan, J.B. 1972. Estimation of genetic parameters in a population of monogerm sugar beet (Beta vulgaris): 1 . Sib-Analysis of mother-line progenies. Irish J. Agric. Res., 11(2): 237-246.

Moosavi, S.G.R., S.H.R. Ramazani, S.S. Hemayati and H. Gholizade. 2017. Effect of drought stress on root yield and some morpho-physiological traits in different genotypes of sugar beet (Beta Vulgaris L.). J. Crop Sci. Biotech., 20(3): 167-174. 
Nasri, R., A. Kashani, F. Paknejad, Shoae M. Sadeghi and S. Ghorbani. 2012. Correlation and path analysis of qualitative and quantitative yield in sugar beet in transplant and direct cultivation method in saline lands. Iran J. Agron. Pl. breed., 8(1): 213-226.

Page, A.L. 1982. "Methods of Soil Analysis" Part II: Chemical and Microbiological Properties. $2^{\text {nd }}$ Ed. Agron. Series (9), ASA, SSSA Madison, Wis; U.S.A.

SCC. 2017. Sugar Crops Council. The annual report of the sugary crops and sugar production in Egypt. Ministry of Agriculture, Egypt (In Arabic).

Silin, P.M. and N.P. Silina. 1977. Chemical control in sugar technology. Food Tech., Pub. USSR, pp 120-126

Sivasubramanian, S. and P. Madhavamenon. 1973. Combining ability in rice. Madras Agric. J., 60: 419-421.

Sklenar, P., L. KovaČev, N. ČAČiĆ, S. Mezei and N. Nagl. 1998. Genetic and phenotypic correlations for some sugar beet root characteristics. In: Tsekos I., Moustakas M. (eds) Progress in Botanical Res. Springer, Dordrecht pp: 569-572.

Snedecor, G.W. and W.G. Cochran. 1994. Statistical Methods. $9^{\text {th }}$ Edition. Iowa State Univ. Press, Ames, Iowa, USA.
Steel, R.G.D., Torrie, J.H. and D.A. Dicky. 1997. Principles and Procedures of Statistics, A Biometrical Approach. 3rd Edition, McGraw Hill, Inc. Book Co., New York, 352358.

Swamy Gowda, S.N., k. Saravanan and C.R. Ravishankar. 2016. Genetic variability, heritability and genetic advance in selected clones of sugarcane. Pl. Archives, 16 (2): 700704.

Tadesse, F. and Z. Dilnesaw. 2014. Genetic variability, heritability and character association of twelve sugar cane varieties in Finchaa Sugar Estate West Wolega zone Oromia region of Ethiopia. Int. J. Adv. Res. Biol. Sci., 1(7):131-137.

Watson, D.J. 1952. The physiological basis of variation in yield. Adv. Agro. 4: 101-145.

Zhang, L., J. Zhou, Y.G. Zhao, Y. Zhai, K. Wang, A.K. Alva and S. Paramasivam. 2013. Optimal combination of chemical compound fertilizer and humic acid to improve soil and leaf properties, yield and quality of apple (Malus domestica). Pakistan J. Bot., 45: 131-132. 


\section{الملخص العربي}

\section{تأثير شاى مخلفات الحمام على بعض القياسات الفسيولوجية والوراثية فى بنجر السكر}

العربى سالم رمضان سالم، سحر فايز توفيق و محمد عبدالمنعم غنيمة

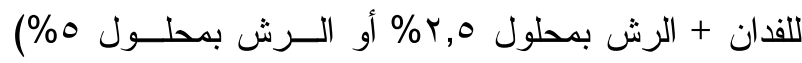
خلال موسمى الدراسة و الذى لم يختلف معنويا عن المستوى الموصى به من السماد النيتروجينى. تم الحصول على أعلى حاصل من الجــذور والأوراق SN- و السكر/فدان و النسبة المئوية للسكروز بو اسطة الصنفي الصنف 626 ، فى حين سُجِّت أقل القيم للصفات السابقة بزر اعــة الصنف Hercule خلال موسمى الزر اعة.

تم در اسة الإختلافات الور اثيـــة و المظهريـــة و البيئيـــة ومعامل الإختلاف الوراثى و البيئى ودرجة التوريث - وقد الإندان إختلفت الصفات المدروسة فى درجة توريثها من المرتفعـة ودئة إلى المنخفضة، حيث كانت مرتفعة بالنسبة لقطر الجذر يليها

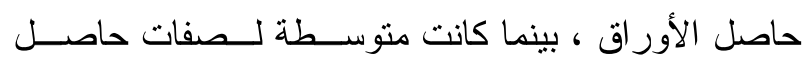
الجذور و السكر و النسبة المئوية للسكروز - في حين كانت منخفضة فى النسبة المئوية للمو اد الـــلبة الذائبــة الكليــة

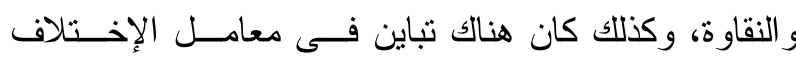

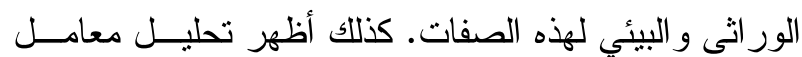

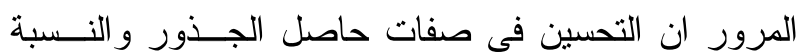
المئوية للنقاوة و السكروز فى الاصناف تحت الدراسة يؤدى

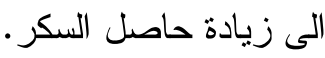

تحت ظروف هذا البحث، يمكـن التوصـية بزر اعــة الصنف SN-626 وتسميده بإضافة ـ كجم نيتروجين للفدان

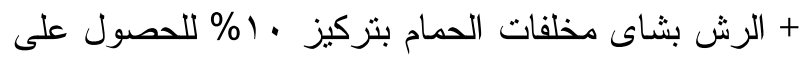

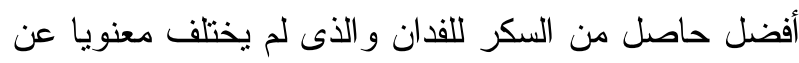

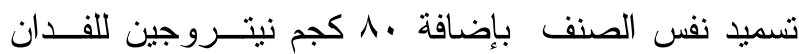

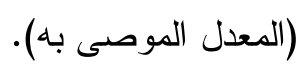

أجريت تجربتان حقليتان بمطة البحوث الزاعية

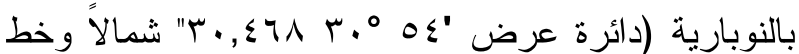

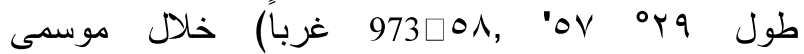

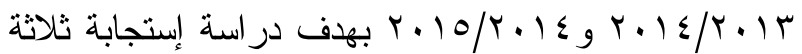
أصناف من بنجر السكر لأربعة توليفات من شاى مُخلّفات الحمام و السماد النيتروجينى المعدنى وتأثير ها على الحاصل ومكوناته وبعض الصفات الكيماوية و المقاييس الفسيولوجية و الور اثية. تم إستخدام تصميم القطع المنشقة فى قطاعات كاملة عشو ائية في ثلاث مكررات. تم إستخدام ثلاثة أصناف

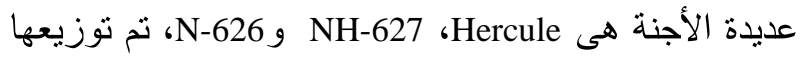

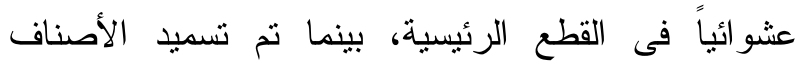

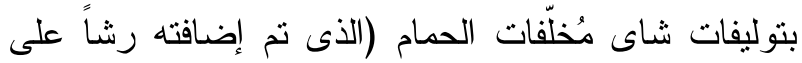
المجموع الخضرى) و السماد النيتروجينى (الذى نت إضافته للتربة تكبيشاً بجو ار النباتات)، حيث تم إضافة هذه التوليفات عشو ائياً فى القطع المنشقة، وهى: 1- إضافة . 1 كجم نيتروجين/فدان (المستوى الموصى به كمقارنة) بدون الرش بشاى مخلفات الحمام. r- الرش بشاى مخلفات الحمام بتركيز ب,0\% + إضافة • ك كجم نيتروجين/فدان. r- الرش بشاى مخلفات الحمام بتركيز 0\% + إضافة .ع

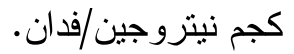

ع- الرش بشاى مخلفات الحمام بتركيز ـ (\% + إضافة • ك كجم نيتروجين/فدان.

أوضحت النتائج أن تسميد بنجر السكر بإضافة ــ كجم نيتروجين للفدان + الرش بمحلول · (\% من شاى مخلفات

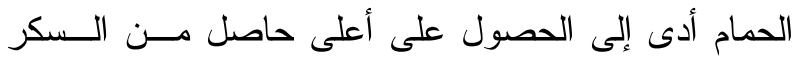
للفدان مقارنة بالتركيزات الاخرى (•؛ كجــ نيتــروجين 
